\title{
Dynamics of changes of bed load outflow from a small glacial catchment (West Spitsbergen)
}

\author{
W. Kociuba, G. Janicki \& K. Siwek \\ Institute of Earth Sciences, \\ Maria Curie-Skłodowska University in Lublin, Poland
}

\begin{abstract}
Fluvial transport in a small glacial river catchment localized in the NW part of Wedel-Jarlsberg Land (Spitsbergen SW) was studied in the summer period of 2009. The intensity of bed load transport was determined using the River Debris Traps constructed for the project's need. The obtained results indicate high dynamics of bed load transport, the amount of which reached up to several dozen $\mathrm{kg}$ for 24 hours in individual measurement sites. The results also confirmed great variability of different fluvial processes in the polar zone.
\end{abstract}

Keywords: small glacial river catchment, bed load transport, bed load sampling, River Debris Trap, Spitsbergen.

\section{Introduction}

The former investigations of fluvial transport in the polar catchment of NW Spitsbergen included analysis of solution and suspension transport, without the measurements of bed load material's transport (Rachlewicz [9], Chmiel et al. [4]) - the main component of transport in a gravel-bed river (Hammer and Smith [6], Warburton [12]). The mechanism and intensity of bed load transport and functioning of proglacial rivers are poorly investigated in this environment. It is mostly the result of a shortage of representative and long-term measuring series as well as standardisation of measurement methodology. The use of direct methods to measure the bed load transport, just as in mountain gravel-bed rivers, is limited by heavy terrain conditions (Bunte et al. [3]). The use of the advanced measurement techniques (luminescence, magnetic, radio-emitters and radioisotope methods) is not possible due to a shortage of infrastructure, particularly energetic (Froehlich [5]). Therefore, elaboration and the putting into 
practice of the new methodology of bed load transport measurement, as well as determination of the elementary value of bed load concentration, were very important research tasks.

The following study is a preliminary elaboration of the investigations concerning the dynamics of changes of bed load transport in a sub-polar gravelbed river, which started in 2009. The studies of fluvial processes were conducted in the summer season (July-September) of 2009 during the $21^{\text {st }}$ Polar Expedition of the Maria Curie-Skłodowska University to Spitsbergen. The investigations were supported by grant from the vice-chancellor for Scientific Research and International Cooperation of the Maria Curie-Skłodowska University.

\section{Study area}

For detailed analysis we chose the catchment of the Scott River (Scottelva), situated in the proximity of the "Calypsobyen" research station of the Maria Curie-Skłodowska University (Figure 1). The analysed catchment, located on the Bellsund Bay in the south-western part of the Wedel Jarlsberg Land (SW Spitsbergen), is about $10 \mathrm{~km}^{2}$ in area. The Scott Glacier, which is at the stage of strong recession, covers more than half of the catchment $(57 \%)$. This valley glacier is less than $4 \mathrm{~km}$ long and from 1.1 to $1.8 \mathrm{~km}$ wide. The glacier front retreated at a rate of $6 \mathrm{~m} /$ year in the 1960s and 1970s, to a maximum $15 \mathrm{~m} /$ year in the 1990s, and about $20 \mathrm{~m} /$ year in recent years (2005-2006) (Zagórski et al. [13]).

The Scott River catchment is diverse in respect of geological and geomorphological conditions. The upper part of the catchment is a glaciated mountain valley, surrounded by mountains ridges composed of Proterozoic

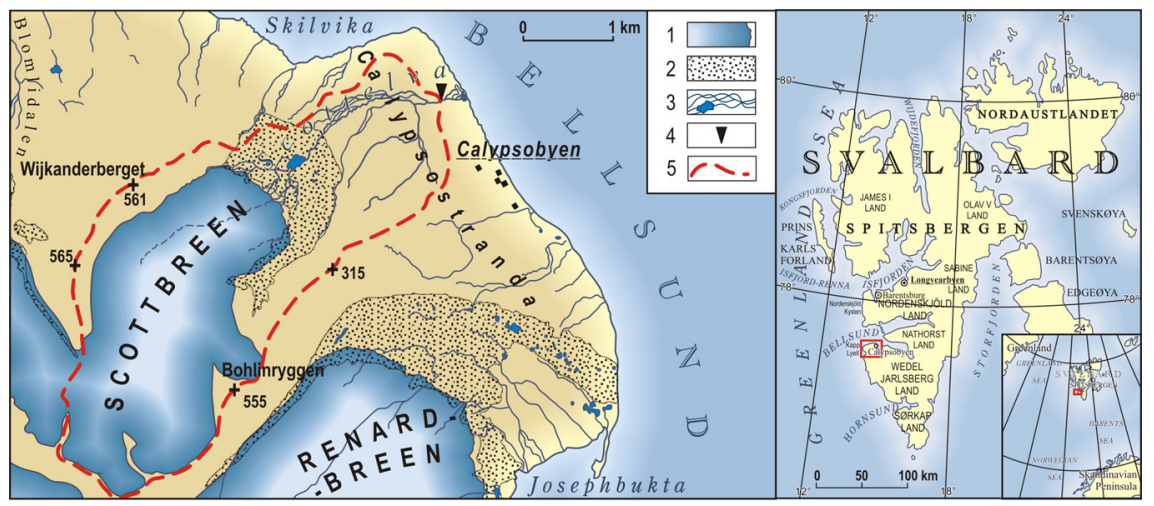

Figure 1: Location of the research area. Situation of the Scott River catchment: 1. valley glaciers, 2. glacial accumulation zones, 3 . rivers and water bodies, 4. location of river gauge and research profiles, 5. catchment boundaries. 
metamorphic rocks (tillites, phyllites and quartzites). Steep and short rocky slopes are modelled by predominant weathering, nival and mass movement processes. A rather wide zone of glaciomarginal relief occurs near the front of the Scott Glacier. In the extra-marginal zone of the Scott glacier the river flows through the gorge of the frontal moraine and creates a large sandur system. The braided river system with variable channel pattern functions in the central part of the catchment.

The non-glaciated part of the Scottelva catchment includes the shore plain called "Calypsostranda", which was uplifted by isostatic movements at 20-120 m a.s.1. (Szczęsny et al. [11]; Reder and Zagórski [10]. The bedrock of Calypsostranda is composed of Mesozoic deposits (gypsum, dolomite, sandstone, shale and mudstone) covered by Tertiary sandstones with hard coal inserts and Quaternary marine (gravel, sand and clay) and glacial (till) deposits (the thickness of the Quaternary deposits varies from several to $20 \mathrm{~m}$ ) (Pękala and Repelewska-Pękalowa [8]). In the lower course, the Scott River forms the gorge dissecting the marine terraces (18-40 $\mathrm{m}$ a.s.1.). In this section of the valley - several dozen metres long - the braided channels join up into one, and further a system of alluvial fans occurs, which closely adjoin the Recherche fiord. The river mouth is separated from the bay by the storm ridge, and water flows through the crevasse (Figure 1).

The Scott River represents a glacial hydrologic regime and ablation waters dominate in its alimentation structure (90\%). The river is also supplied with rainfall (4\%), nival (4\%) and permafrost (about 2\%) waters. The mean annual outflow from the Scott River catchment is about $900 \mathrm{~mm}$, and the mean discharge over a period of many years is estimated at about $900 \mathrm{dcm}^{3} \cdot \mathrm{s}^{-1}$, which corresponds to the specific discharge of $90 \mathrm{dcm}^{3} \cdot \mathrm{s}^{-1} \cdot \mathrm{km}^{2}$ (Bartoszewski [1]). The Scottelva is characterized by a great variability of river stages and irregular discharge - daily, seasonal and over a period of many years. The maximum flood discharges caused by the increase in air temperature or/and high precipitation reach $12 \mathrm{~m}^{3} \cdot \mathrm{s}^{-1}(7-9.08 .1993)$. The Scott River has several small tributaries supplied with snow-permafrost waters, and the greatest of them is the Renifer Stream draining the eastern part of the sandur (Bartoszewski [1]).

\section{Methods of research}

The hydrometric station and the traps for fluvial transport measurements were located on the Scott River, in the place where the braided channels join up into one, $350 \mathrm{~m}$ from its mouth to the fiord (Figure 1). This location was similar to that of hydrographical monitoring in previous years (Bartoszewski [1], Bartoszewski et al. [2]). The hydrographical research included continuous measurement of the river stage in the channel with the use of a pressure electronic limnograph and analyses of the main physico-chemical features (temperature, conductivity). Measurements of water velocity in the cross profile were made using a hydrometric current meter.

In order to determine the dynamics of bed load transport, the direct measurement methods of dragging intensity were used. The traditional traps are 
usually operated directly in the river or from a boat, pontoon, footbridge or bridge. The solutions applied at the Polish Hydrometeorogical Institute (PIHM), as well as Helley-Smith traps, need the standing presence of a researcher during the measurements. This methodology limits the time of sample collection to short-term periods ipso facto results in poorer quality of the obtained results. During high water stages and high suspended sediment concentration there are no possibilities to control a trap arrangement in the channel bed and its lack of stability can disturb the measurement. In the case of PIHM traps, the heavy weight and size of equipment causes limited possibilities to use it in the conditions of high energetic mountain river flow. Bunte et al. [3] partly solve this problem using traps stabilized in the river bed, but it is effective in terms of low and balanced flows only. During the raised water stage servicing these traps requires a minimum of three persons protected with ropes, but changing of the traps is connected with the researchers' immersion in the water. In the mountain rivers environment in the low temperatures this limits the possibilities and time of measurement.

These shortcomings are eliminated by the construction of an all-purpose, light and portable equipment to measure bed load transport in river channels - River Debris Traps [RDT] constructed by W. Kociuba (Figure 2). The advantages of

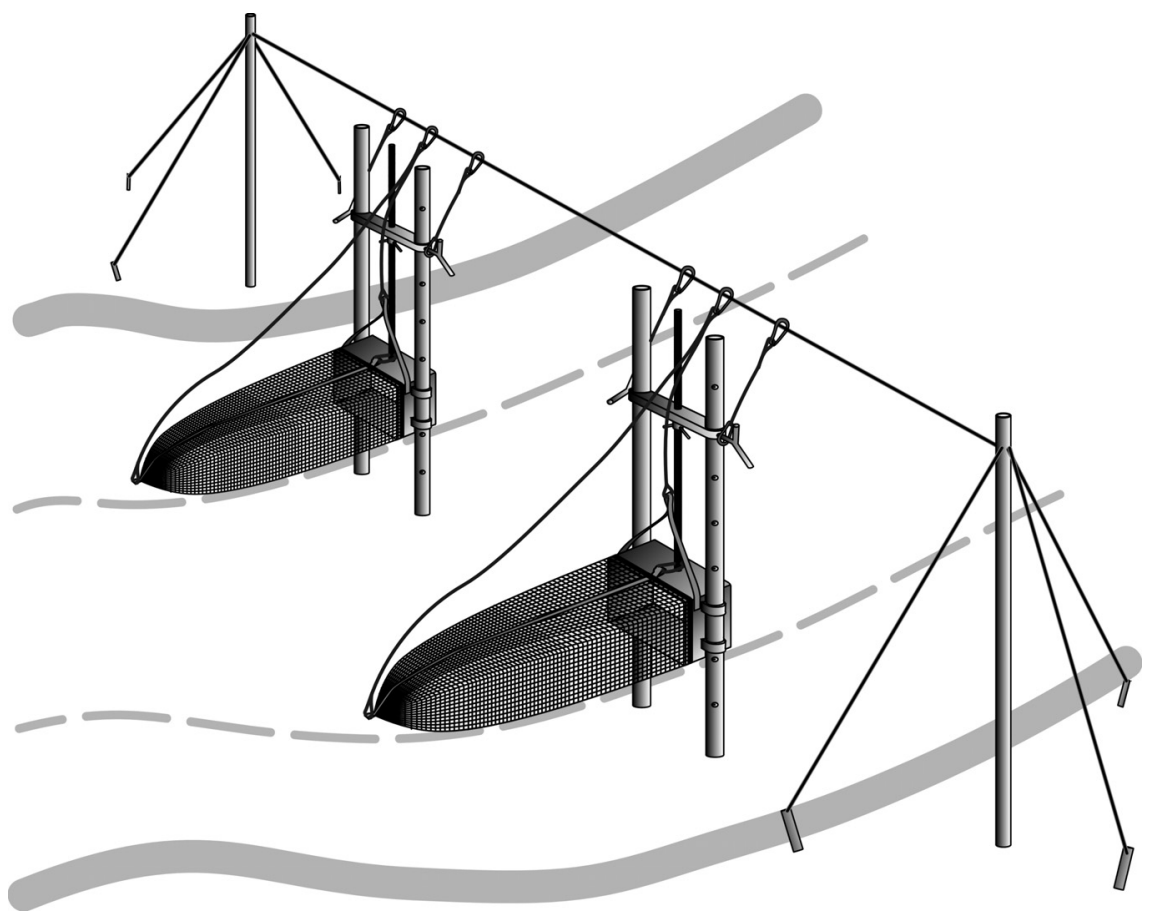

Figure 2: Example of arrangement of two River Debris Trap (RDT) sets and systems of protection in cross section. 
this equipment are the following: recurrence of measurements conducted in the time intervals adjusted to the flow regime with integrated monitoring, one-man service and carrying out the measurement independently of environmental conditions in the catchment as well as climate parameters. The use of the set of RDT traps allow one to examine the bed load material movement, which determines the conditions of the commencement of movement and intensity of bed load material transport. The devised measurement method (uninterrupted procedure with samples collected every 24 hours) allows one to determine the interrelations between the discharge rate and elementary bed load transport rate, the grain size distribution of bed load material in the separate measurement profiles and threshold values of movement of individual bed load fractions, as well as main routes of transport.

The working out and implementation of the original method of measurement of bed load transport resulted in the submission of an application for patent protection for the River Debris Trap in December 2009 (no. of application WIPO ST 10/C PL389882).

Sediment transport was measured using the River Debris Traps, which were placed in four measurement sites in the channel cross profile. The caught material was weighed and photographed separately for the each measurement site every 24 hours (Figure 3). River sediment transport was measured from July

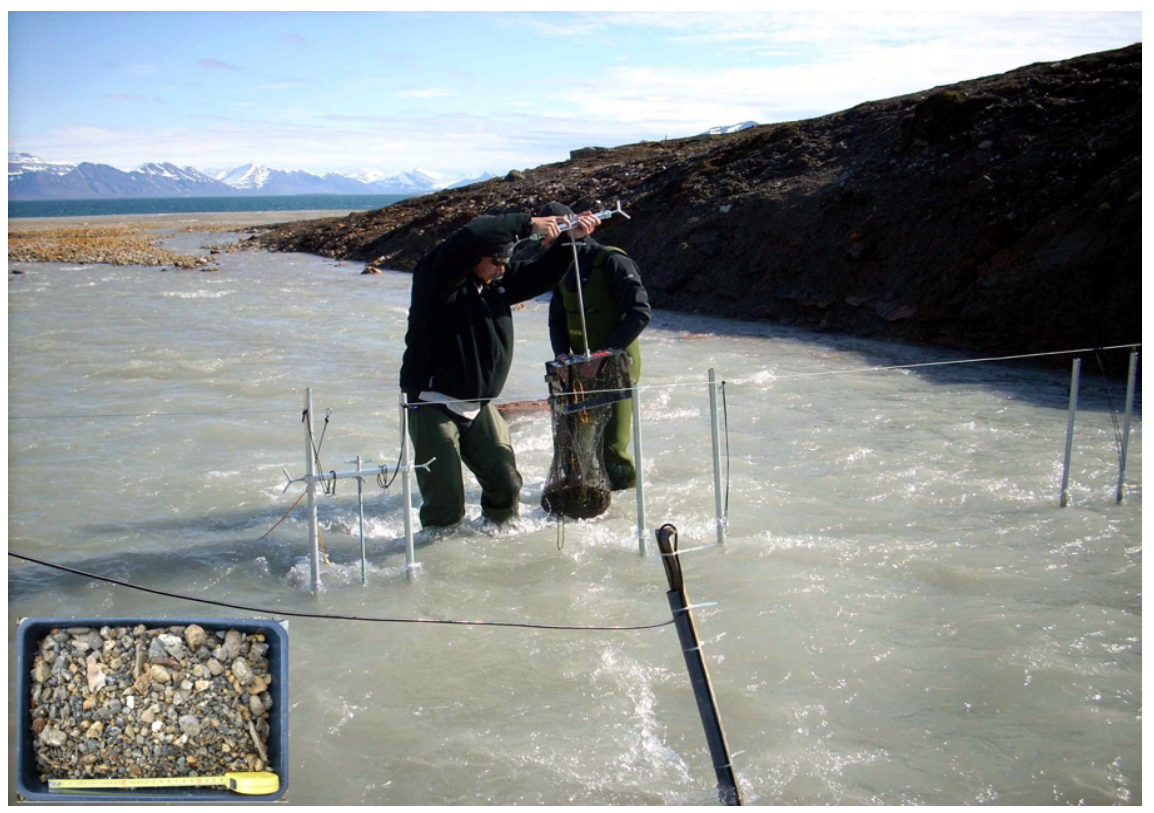

Figure 3: The set of river debris traps in the cross profile of the Scottelva. Mass of bed load material caught during 24 hours in one of the measurement sites in the cross profile of the Scottelva (photo by K. Siwek). 
$10^{\text {th }}$ to September $7^{\text {th }} 2009$, i.e. from the time when the whole profile of the river channel emerged from snow-ice cornices on the river banks to the time when the channel bed started to freeze. In total 227 samples were taken on 54 measurement days.

The fieldwork also included a geomorphological survey and identification of the permanent and ephemeral macro-, meso- and microforms in the valley and channel. The main parameters of valley floor geometry were determined along the selected research profiles in the selected test areas using a laser tachimeter. The degree of coupling between the slope and channel subsystems was estimated based on the cubature of main (with cross-section $>1 \mathrm{dcm}^{2}$ ) erosion and depositional slope forms.

The main meteorological variables, such as air temperature and precipitation level, were recorded every ten minutes by an automatic meteorological station. The station is situated on the Calypsostranda shore plain (23 $\mathrm{m}$ a.s.l.) covered by patch tundra vegetation, about $200 \mathrm{~m}$ from the Recherche Fiord shore, near the research station of the Maria Curie-Skłodowska University.

\section{Results}

In the summer period of 2009 the course of weather and meteorological conditions was such as in other years and no weather anomalies occurred. The air temperature in the measurement period ranged from $+2.0^{\circ} \mathrm{C}$ to $+7^{\circ} \mathrm{C}$, with the average of $+4.9^{\circ} \mathrm{C}$ (Figure 4). The precipitation total in the measurement period $(18.1 \mathrm{~mm})$ was slightly higher than that over a period of many years. During the observed 16 precipitation days, the maximum daily total did not exceed $5 \mathrm{~mm}$

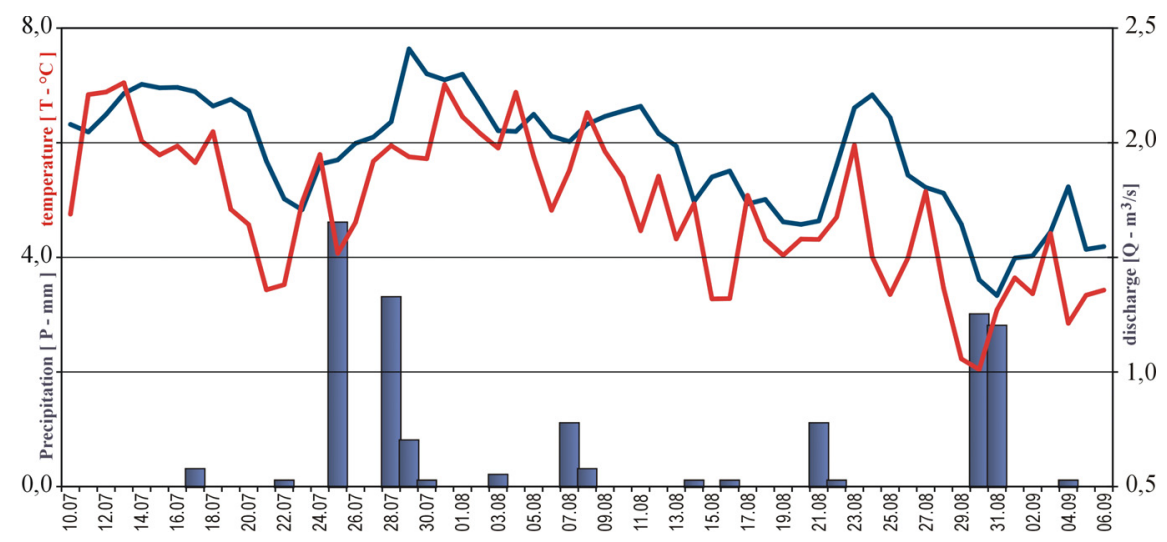

Figure 4: Comparison of the run of changes of average daily air temperature and average daily precipitation total in the "Calypsobyen" research station of the Maria Curie-Skłodowska University with the average daily discharge in the Scott River in the summer season of 2009: $\mathrm{H}$ - precipitation, Q - daily discharge, $\mathrm{T}$ - average daily air temperature. 


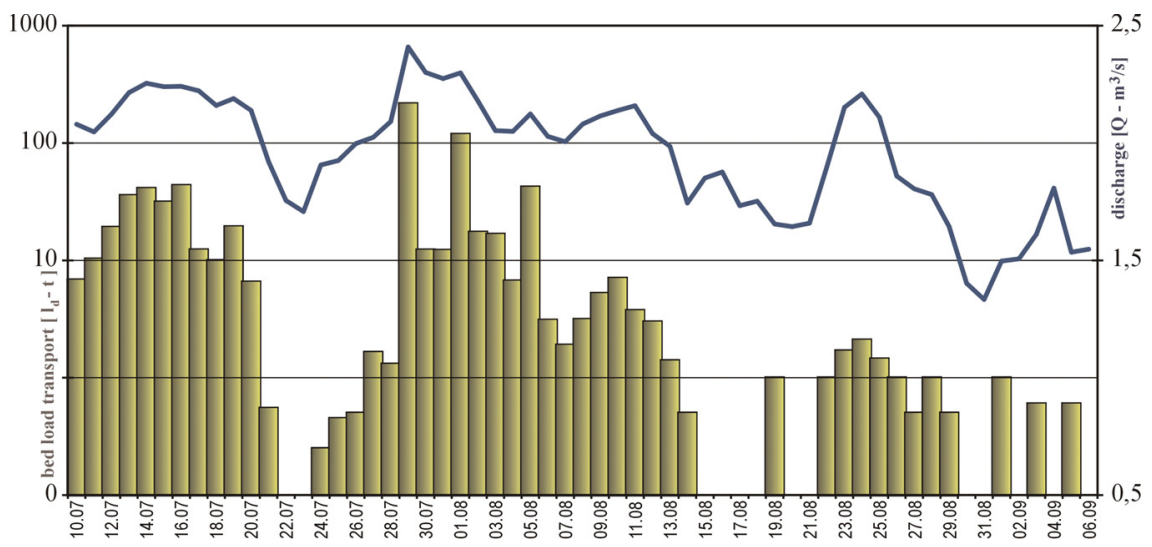

Figure 5: Daily values of bed load concentration $(t)$ and discharge $\left(\mathrm{m}^{3} / \mathrm{s}\right)$ in the Scott River in the summer season of 2009.

and differed considerably from the previously recorded maxima (36 mm) in 1993 (Bartoszewski et al. [2]).

In the summer season of 2009 the water stage in the Scott River channel ranged from 7 to $22 \mathrm{~cm}$ and the average daily discharge (from 1.3 to about 2.4 $\mathrm{m}^{3} \cdot \mathrm{s}^{-1}$ ) was similar to average values. Both water stages and discharges rather well corresponded to the run of average daily air temperature and daily precipitation total.

The obtained results indicate a great variability of dynamics of bed load transport in the conditions of rather stable discharge: from 1.3 to $2.4 \mathrm{~m}^{3} \cdot \mathrm{s}^{-1}$, with the mean value of $2.0 \mathrm{~m}^{3} \cdot \mathrm{s}^{-1}$, both in daily cycle and in the whole measurement period (Figure 5). The amount of bed load caught in the particular measurement sites ranged from 0 to $66 \mathrm{~kg}$ for 24 hours. The mean daily transport in the particular measurement sites was $1.3,3.8,3.3$ and 4.7 , and the average daily value was $3.3 \mathrm{~kg}$. The maximum daily values (from 41.5 to $66 \mathrm{~kg}$ ) were recorded during the flood on July $29^{\text {th }} 2009$. These values constituted from $20 \%$ to $50 \%$ of the total mass measured in the particular measurement sites. The total bed load mass caught in the particular measurement sites was 77, 210, 191 and $275 \mathrm{~kg}$ (in total $753 \mathrm{~kg}$ ). Therefore, the bed load transport in the channel cross profile can be estimated at almost $100 \mathrm{~kg}$ for 24 hours, i.e. about $6 \mathrm{t}$ during the measurement period.

The analysis of daily distribution of the bed load values indicates spatial and temporal differentiation of bed load transport (Figure 6). The increase in bed load mass in the particular measurement sites from the southern to the northern river-bank (from S1 to S4) was distinctly marked for the whole measurement period. On particular days the highest daily loads were alternately measured in the sites located in the thalweg zone (S3 and S4), although the daily maximum load $(66 \mathrm{~kg})$ was caught in the S2 measurement site. This fact enables us to conclude that transport routes shift in the channel cross profile. 


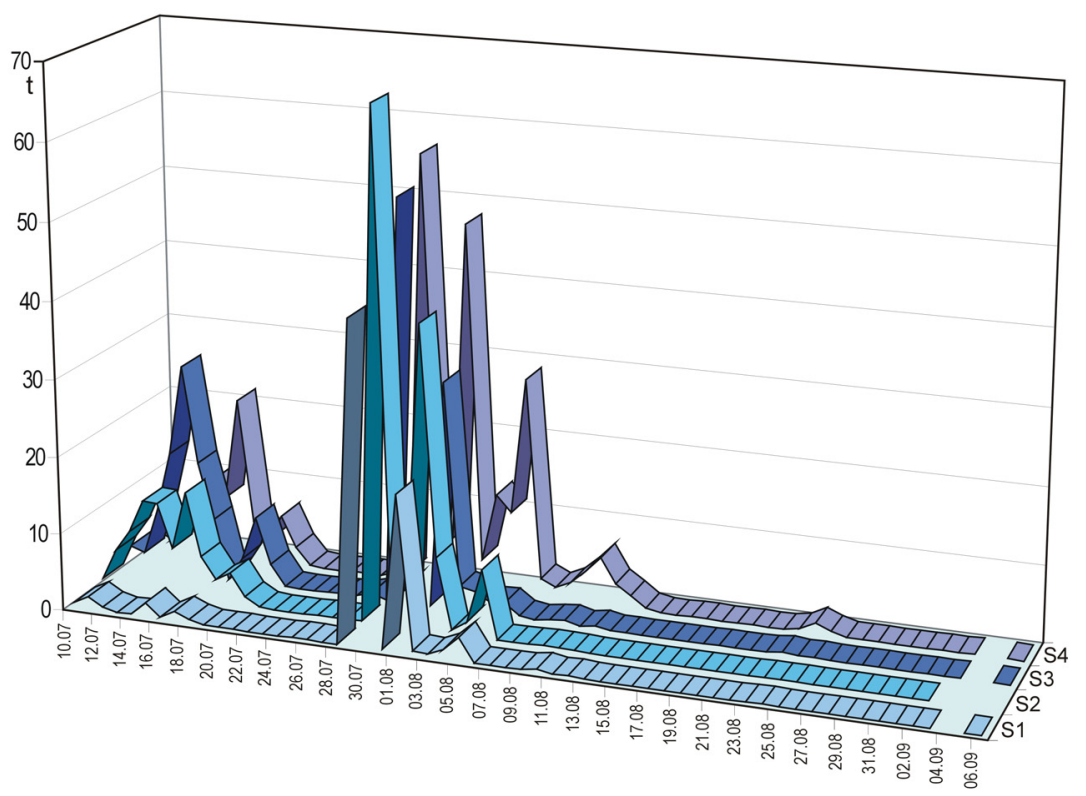

Figure 6: Daily values of bed load concentration $(\mathrm{t})$ in the particular measurement sites of the Scott River cross profile in the summer season of 2009.

In respect of bed load transport variability, the measurement period was distinctly divided into two parts. In the first half (from July $9^{\text {th }}$ to August $9^{\text {th }}$ of 2009) the elementary rate of bed load transport was considerably more variable in the particular sites and days. In the second half (from August $10^{\text {th }}$ to September $7^{\text {th }}$ of 2009) daily bed loads were usually low and not related to discharge values (Figure 6).

The relation between bed load transport rate and discharge changes was different in two parts of the measurement period due to spatial and temporal differentiation of material supply to the channel. In the first part of the measurement period the channel was supplied with slope material redeposited directly to the channel. With the melting of snow patches the mass movement processes were triggered on the southern side of the valley gorge section. This phenomenon resulted in the rather high values of elementary rate of bed load transport in the S1 and S2 measurement sites. In the second part of the measurement period, with stabilization of the valley sides, the Scott Glacier became the main source of material supply. Generally, a lower discharge and long distance of transport favoured selective erosion, resulting in the formation of a channel pavement. For that reason the critical velocity of flow necessary to initiate bed load movement was higher. This fact resulted in the diametrically different amounts of bed load transported in successive days, although the discharge rate was similar (Kociuba et al. [7]). 


\section{Conclusions}

The results of investigations conducted in the research profile of the Scottelva in the summer season of 2009 indicated a great temporal and spatial variability of bed load transport, the amount of which in individual measurement sites ranged from zero to several dozen kilograms for 24 hours. The increased sediment load in the river water was accompanied by considerable changes of channel geometry. We registered more intensive down-cutting and processes of lateral and vertical accretion of deposits: formation of bars, gravel shadows, levees and building up of channel bed.

The investigations undertaken with the application of the new survey methodology indicated a great temporal and spatial variability of fluvial processes conditioned by hydro-climatic factors - particularly glacier condition and ablation rate, glacier extent in the catchment, thickness of the permafrost active layer and weather and thermal conditions - determining the discharge value.

\section{References}

[1] Bartoszewski S., Reżim odptywu rzek Ziemi Wedel Jarlsberga (Spitsbergen). Wyd. UMCS, Lublin, pp. 1-167. 1998

[2] Bartoszewski S., Gluza A., Siwek K., Zagórski P., The functioning of Scott Glacier in conditions of climate global changes. Landform Analysis, 5, pp. 5-8. 2007

[3] Bunte K., Potyond J., P., Abt S., Sampler size and sampling time affect measured bedload transport rates and particle sizes measured with bedload traps in gravel-bed streams, [in]: Erosion and Sediment Transport Measurement in Rivers: Technological and Methodological Advances. J. Bogen, T. Fergus and D.E. Walling (eds.), IAHS-Publication No. 283, pp 126-133. 2003

[4] Chmiel S., Bartoszewski S., Gluza A., Siwek K., Zagórski P., Physicochemical characteristic of land waters in the Bellsund region (Spitsbergen). Landform Analysis, 5, pp. 11-13. 2007

[5] Froehlich W., Akustyczne i magnetyczne badania transportu ładunku dennego, [w:] Florek W., Kaczmarzyk J., (red.), Współczesne problemy geomorfologii, Landfom Analysis, 9, pp. 348-350. 2008

[6] Hammer K.M., Smith N.D., Sediment production and transport in proglacial stream: Hilda Glacier, Alberta, Canada. Boreas, 12, pp. 91-106. 1983

[7] Kociuba W., Janicki G., Siwek K., Variability of sediment transport in the Scottelva catchment in the hydrologically active season of 2009. Questiones Geographica A. in press

[8] Pękala K., Repelewska-Pękalowa J., Dynamics of active layer of permafrost. Landform Analysis 5, pp. 168-169. 2007 
[9] Rachlewicz G., Floods in high Arctic Valley systems and their geomorphologic effects (examples from Billefjorden, Central Spitsbergen). Landform Analysis, 5, pp. 66-70. 2007

[10] Reder J., Zagórski P., Recession and development of marginal zone of the Scott Glacier, Landform Analysis 5, pp. 175-178. 2007

[11] Szczęsny R., Dzierżek J., Harasimiuk M., Nitychoruk J., Pękala K., Repelewska-Pękalowa J., Photogeological map of Renardbreen, Scottbreen and Blomlibreen Forefield (Wedel Jarlsberg Land, Spitsbergen), scale 1:10 000. Wydawnictwa Geologiczne, Warszawa. 1987

[12] Warburton J., An alpine proglacial fluvial sediment budget. Geografiska Annales, 72A, pp. 261-272. 1990

[13] Zagórski P., Siwek K., Gluza. A., Bartoszewski S., Changes in the extent and geometry of the Scott Glacier, Spitsbergen, Polish Polar Research, 29, 2, pp. 163-185. 2008 